\title{
Author Correction: Novel mutations in PIEZO1 cause an autosomal recessive generalized lymphatic dysplasia with non-immune hydrops fetalis
}

\author{
Elisavet Fotiou ${ }^{1,11}$, Silvia Martin-Almedina ${ }^{1,11}$, Michael A. Simpson ${ }^{2}$, Shin Lin ${ }^{3,4}$, Kristiana Gordon ${ }^{5}$, Glen Brice ${ }^{6}$, \\ Giles Atton ${ }^{6}$, Iona Jeffery ${ }^{7}$, David C. Rees ${ }^{8}$, Cyril Mignot ${ }^{9}$, Julie Vogt ${ }^{10}$, Tessa Homfray ${ }^{6}$, Michael P. Snyder ${ }^{4}$, \\ Stanley G. Rockson ${ }^{3}$, Steve Jeffery ${ }^{1}$, Peter S. Mortimer ${ }^{1}$, Sahar Mansour ${ }^{6}$ \& Pia Ostergaard ${ }^{1}$
}

Correction to: Nature Communications https:/doi.org/10.1038/ncomms9085, published online 03 September 2015.

This Article contains an error in the last sentence of the 'Variant analysis suggests they are pathogenic' section of the Results, which incorrectly reads 'No truncated PIEZO1 protein products were identified in western blot analysis in GLD1:II.3 and GLD2:II.2 (Fig. 2, Supplementary Fig. 6), suggesting that the truncated protein is not stable and therefore degraded'. This should read 'No full-size PIEZO1 protein products were identified in western blot analysis in GLD1:II.3 and GLD2:II.2 (Fig. 2, Supplementary Fig. 6); the three nonsense mutations are predicted to lead to premature termination of the protein, hence it is possible that those truncated proteins will be non-functional or even unstable and degraded'. The error has not been fixed in the PDF or HTML versions of the Article.

Published online: 26 April 2019

Open Access This article is licensed under a Creative Commons Attribution 4.0 International License, which permits use, sharing, adaptation, distribution and reproduction in any medium or format, as long as you give appropriate credit to the original author(s) and the source, provide a link to the Creative Commons license, and indicate if changes were made. The images or other third party material in this article are included in the article's Creative Commons license, unless indicated otherwise in a credit line to the material. If material is not included in the article's Creative Commons license and your intended use is not permitted by statutory regulation or exceeds the permitted use, you will need to obtain permission directly from the copyright holder. To view a copy of this license, visit http://creativecommons.org/licenses/by/4.0/.

(C) The Author(s) 2019

\footnotetext{
${ }^{1}$ Cardiovascular and Cell Sciences Institute, St. George's University of London, Cranmer Terrace, London SW17 ORE, UK. ${ }^{2}$ Department of Medical and Molecular Genetics, Division of Genetics and Molecular Medicine, Kings College London School of Medicine, Guy's Hospital, London SE1 9RY, UK. ${ }^{3}$ Division of Cardiovascular Medicine, Stanford University, Stanford, California 94305, USA. ${ }^{4}$ Department of Genetics, Stanford University, Stanford, California 94305 , USA. ${ }^{5}$ Department of Dermatology, St. George's Healthcare NHS Trust, London SW17 OQT, UK. ${ }^{6}$ South West Thames Regional Genetics Unit, St. George's University of London, London SW17 ORE, UK. ${ }^{7}$ Pathology Department, St. George's University of London, London SW17 ORE, UK. ${ }^{8}$ Department of Haematological Medicine, King's College London School of Medicine, King's College Hospital, London SE5 9RS, UK. ${ }^{9}$ Département de Génétique, APHP, GH Pitié-Salpêtrière, Centre de Référence des Déficiences Intellectuelles de Causes Rares, 75013 Paris, France. ${ }^{10}$ West Midlands Regional Genetics Service, Clinical Genetics Unit, Birmingham Women's Hospital, Birmingham B15 2TG, UK. ${ }^{11}$ These authors contributed equally: Elisavet Fotiou, Silvia Martin-Almedina. Correspondence and requests for materials should be addressed to P.O. (email: posterga@sgul.ac.uk)
} 